\title{
The structure and relations of banking systems: the UK experience and the challenges of 'levelling- up'
}

\author{
Colin Mayer,* Philip McCann,** and Jacob Schumacher***
}

\begin{abstract}
A decentralized banking system is marked by geographical dispersion of banks with close proximity of banks to their borrowers and strong long-term relationships between banks and their borrowers based on soft, tacit, as well as hard, codified information. It is important for promoting the development of small and medium-sized enterprises (SMEs) particularly in regional locations. In contrast, the UK has a highly centralized, concentrated banking system with weak relationships between banks and their borrowers. This has contributed to the high degree of regional disparity across the UK. The programme of 'levelling up' regions will require a more decentralized banking system. The cases of Germany, the US, and the Swedish bank Handelsbanken illustrate the advantages of decentralized banking. They also have important lessons for the way in which decentralized banking systems should be structured and organized and, in particular, for the regulatory arrangements that are conducive to their satisfactory functioning and avoidance of pitfalls to which they can otherwise be prone.
\end{abstract}

Keywords: decentralized banking, banking systems, relationship banking, small and medium-sized enterprises, regional disparities, tacit knowledge, bank regulation

JEL classification: G21, G28, R51

* Saïd Business School, University of Oxford; e-mail: colin.mayer@sbs.ox.ac.uk

** Sheffield University Management School; e-mail: p.mccann@sheffield.ac.uk

*** St Edmund Hall, Oxford; e-mail: jacob.schumacher@seh.ox.ac.uk

The authors are very grateful to Chris Adam and an anonymous referee for very helpful comments on a previous version of this paper.

\section{Introduction}

In this paper we consider the role played by the nature and structure of banking systems in fostering local economic development, and in particular we reflect on the experience of the UK's highly centralized system in the light of the experience of other more devolved systems. Our focus is not on the provision of general financial services but on credit relationships, the arena where information asymmetries play an important role and where we will argue that relationship banking works most effectively. We examine evidence of the role played by decentralized relationship- 
type banking operating via intense and reciprocal knowledge exchanges between banks and their customers. It is well known in economic geography that 'soft' or tacit non-codifiable knowledge mediated via frequent face-to-face contact plays a central role in the agglomeration and clustering processes (Gertler, 2005). This is in contrast to 'hard' codifiable knowledge, which can be formulated in terms of information and data and is heavily deployed by centralized banking models. So there are a priori arguments to suggest that relationship banking may play a specific role in local economic development in ways that are not possible with centralized corporate banking models. There has been a variety of somewhat ad hoc and anecdotal evidence on these points for many years, but it is only in the last decade and half that comprehensive and robust micro-data evidence has become available which allows researchers also to tackle questions of identification, endogeneity, and causality in their analyses.

The key issue we highlight is the role played by relationship banking systems in other countries, in marked contrast to the UK experience, and our review of the international evidence suggests that this may be both a major cause of UK interregional inequalities, especially in the small and medium-sized enterprise (SME) arena. This also allows us to point towards possible policy and regulatory steps which could be taken as part of a broader 'levelling up' agenda. The rest of the paper is organized as follows. The next section examines the performance and implications of different types of banking systems, and in the third section these insights are then examined in the context of UK-specific experience. The fourth section considers the experience of three specific examples of relationship banking from Germany, the USA, and Sweden, and in the fifth section we reflect on the potential lessons these examples offer for the UK. The concluding section provides some further directions for consideration, especially regarding the UK devolution and levelling up agenda.

\section{Decentralized versus centralized banking systems: relationships or systems}

In broad terms banks can be considered as being centralized or decentralized on the basis of the operational distance between agents within the firm (Miles et al., 1978; Whittington, 2006), the geographic distribution of its establishments (Petersen and Rajan, 2002), or the functional distance 
between a bank's decision centres and the customers (Alessandrini et al., 2005). In addition to these features, however, within the finance literature, decentralized banking is viewed more as a specific form of banking type and banking activity (Boot, 2000) in which there are deep and longstanding relationships between the banks and the customers which allow for the sharing of customer-specific, and often proprietary information, permitting the evaluation of the profitability of bank and customer investments through multiple interactions with the same customer over time and across products. In this type of relationship banking, direct interactions between the bank and the borrower allow the bank not only to gather, but also to verify, information about potential borrowers, and this may provide higher quality information about borrowers because banks have full control over the process through which they gather and assess information from borrowers. As such, a key aspect here is the role of so-called 'soft information'. Whereas 'hard information' can be relatively easily expressed in numerical form and can be transmitted to others with full understanding largely independent of the context through which it was generated, 'soft information' cannot be easily expressed in numerical form and cannot be understood outside of the context in which it was generated (Berger and Udel, 2002; Liberti and Petersen, 2018), and it is this soft information on which relationship banking relies.

Another consequence of the trust relationships characteristic of decentralized relationship banking is the ability to lend at scope across multiple financial products to the same customers (Hauswald and Marquez, 2006; Puri et al., 2017), thereby further cementing long-standing bank-customer relationships (Boot and Thakor, 1994; Hasan et al., 2019). This allows these types of banks to provide additional value to their customers as well as gathering the information needed to provide these banking services. Indeed, customer surveys among those working with decentralized banks also shows that they derive additional value from the relationship beyond simply providing information to receive financial services (Kroner, 2011). However, the generation of this type of high-quality 'soft' information is costly (Alessandrini et al., 2009; Agarwal et al., 2018), and to be able to establish this type of relationship banking, it is necessary for the bank to have an organizational and locational structure that can promote it - namely, a decentralized structure. 
For our purposes here, we therefore define a decentralized bank as one that provides relationshipbased banking services to its customers by operating in close proximity to them and via a business model that relies on cultivating and utilizing the strong relationship it establishes with its customers to gather and build soft information (Berger and Udell, 2002; Stein, 2002; Berger et al., 2004; Reitzig and Maciejovsky, 2014). As such, relationship banking can be broadly contrasted with transactional banking, a domain feature of centralized banking, where a strong relationship is not established and the intermediaries' interaction with customers is strictly to facilitate transactions based primarily on hard information (Heffernan, 2004). Of course, if a country is very monocentric in terms of its spatial structure, with commercial headquarter functions often heavily concentrated in one region, this would tend to mean that its banking system is likely to be more centralized in purely geographical terms than in a country which is more spatially decentralized. However, the emphasis of our definition is on the nature of relations between the bank and its customers and, indeed, one of the decentralized cases we examine shortly, namely Handelsbanken, arises also from a country which is largely monocentric in spatial organization, namely Sweden.

In the nineteenth century, banking in the UK was a highly geographically diversified sector and local industrialists, philanthropists, and banks played a key role in the building of modern cities across the UK, mainland Europe, Australasia, and North America (Mayer, 2013, 2018). However, throughout the twentieth century, but especially during the last four decades, there has been a widespread movement towards bank centralization in the UK and the US and a progressive decline in relationship banking due to increased competition and mergers in financial services, technological changes, increased securitization and other forms of financial engineering, and deregulation (Becketti and Morris, 1992; Boyd and Gertler, 1993, 1995; Krahnen and Schmidt, 2004; Beck et al., 2010). Many banks in the US and UK moved towards a business model of universal banking in order to diversify activities, and technology played a key role here. The information technologies deployed within bank IT departments have made it possible to quickly gather, process, analyse, and react to hard information, and the presence of credit-rating agencies which provide much of this hard information allows for the further externalization of many of the information generation and processing costs. While final decisions on making a loan may lie within parts of the bank hierarchy other than the IT department, the ability to separate this gathering and processing from decision-making greatly reduces costs of bank lending. 
However, these developments may have come at a price. John Kay (2016) describes the consequences of financial engineering and securitization on the Halifax Building Society in the UK. And while fintech may have increased the efficiency of collecting and processing hard, codified information, it may have come at the expense of soft, tacit information. The public availability of hard information, such as algorithm-based credit ratings, tends to lead to the spatial clustering of banks in well-served locations, while other often smaller locations lose out as access to credit deteriorates even further (Qi et al., 2018). These results are robust after controlling for issues of endogeneity using instrumental variable and placebo regressions (Qi et al., 2018). Similarly, centralized banking systems tend to use deposits collected in peripheral local areas to fund credit in core areas (Verdier, 2009). US-wide evidence on the geographical distribution of deposits, loans, and banking structures, confirms that multi-state branch networks contribute significantly to the overall flows of credit without increasing bank risks (Goetz et al., 2016), but these credit flows particularly favour larger and richer localities (Verdier, 2009; Aguirregabiria et al., 2019). These findings are robust, after controlling for endogeneity using GMM-difference-indifferences estimations and a series of counter-factual experiments (Aguirregabiria et al., 2019) as well as instrumental variable techniques (Goetz et al., 2016). These distortionary credit effects favouring larger more prosperous localities are, at the same time, exacerbated by the more limited banking competition in weaker areas which itself further limits credit availability (Aguirregabiria et al., 2019). Evidence from the US suggest that physical distance between a small firm and a large bank limits the 'soft' information available to a bank in assessing credit worthiness, thereby reducing the likely availability of credit (Agarwal and Hauswald, 2010). Data from Italy also point to reduced credit availability and higher credit pricing associated with geographical distance between the bank and the borrower (Belluci et al., 2014), while data from Brazil suggest that geographical peripherality is also associated with more unstable credit availability though cyclical upswings and downswings (Crocco et al., 2014).

While these banking centralization processes may have increased some, but not all (Alessandrini et al., 2009) aspects of bank efficiency (Berger et al., 2017; Belluci et al., 2019), the firms which often appear to have been relatively disadvantaged by these changes are SMEs (Berger and Udell, 1995; Berger et al., 2004, 2017; Canales and Nanda, 2012), and particularly those in more distant 
locations (Degryse and Ongena, 2005; Jiménez et al., 2009). After controlling for possible endogeneity via the use of differential lag structures (Conroy et al., 2017), system-GM methods (Hasan et al., 2019), or sample selection (Mercieca et al., 2009), local relationship-type banking appears to be especially advantageous for SMEs (Mercieca et al., 2009; Conroy et al., 2017; Hasan et al., 2019). In contrast, after controlling for endogeneity and selection using instrumental variable, conditional models, and system-GMM techniques, it is clear that SMEs in places in which the local banking system is functionally distant are at a disadvantage, especially with regard to their innovation activities (Alessandrini et al., 2009, 2010). As such, the withdrawal of these services and a move towards more transactional centralized banking would appear to be harmful for the SME sector in weaker regions. Moreover, neither venture capital nor angel investment activities appear able to mitigate these changes (Tenca et al., 2018; Grilli, 2019). At the same time, these centralization processes may also exacerbate economic downturns. Using both differencein-differences and instrumental variable estimations, Nguyen (2019) finds that US bank branch closings led to persistent falls in local small business lending and that the effect is particularly severe in recessions. Moreover, these adverse effects last for up to 6 years and are localized to within 6 miles of the branch closings (Nguyen, 2019), suggesting that SME credit markets are still fundamentally a local issue. In contrast, one of the internationally observed features of decentralized banking appears to be its ability to dampen the effects of economic downturns (Jimenez, et al., 2012; Iyer et al., 2014; Gobbi and Sette, 2014; Sette and Gobbi, 2015; Puri et al., 2017), especially for regions which are more severely affected by economic downturns.

\section{Centralized banking and credit availability: the UK sectoral and regional experience}

These international insights would all appear to be particularly pertinent to the current UK 'levelling up' debates where there are strong arguments that the nature and operation of the UK banking and financial systems play a key causal role in the existence and growth of these interregional inequalities. Here there are two key features of the UK economy which need to be considered, namely: first, that there is a clear (and potentially growing) geographical divide between London and its hinterland and the rest of the country in terms of access to investment capital; and second, that there are particular sub-sectors of the commercial landscape which are 
essential for national productivity growth and which appear to be especially disadvantaged by these geographical banking divides. As with the international evidence, in the case of the UK, for many years there has been a mixture of rather ad hoc evidence, but only in the last decade has detailed micro-level evidence emerged which allows us to analyse these issues while also addressing issues of identification, endogeneity, and causality.

On the first point regarding the geographical divide in banking and finance, there is a lot of evidence that financial relationships in the core parts of the economy, namely London and its hinterland, operate in quite different ways to the rest of the country (McCann, 2016). Moreover, there is evidence that these divides may be getting bigger. The aftermath of the 2008 global financial crisis led to a significant geographical restructuring of UK banking. In the UK, of the 600 bank branch closures between April 2015 and April 2016, over 90 per cent were in areas with a below median household income (Qi et al., 2018), whereas two-thirds of all bank branch openings were in wealthier neighbourhoods (Reuters, 2016). Of course, as well as bank lending, there are also other sources of investment finance, such as venture capital and angel investing, but again there is a clear divide between the nature, scale, and operation of these markets in and around London versus the rest of the country (Mason and Harrison, 2003; Mason and Pierrakis, 2013; McCann, 2016). These geographical patterns of bank restructuring prima facie would appear to be contributors to the ongoing processes of $\mathrm{UK}$ regional divergence.

On the second point, it is SMEs which appear to be especially affected by these issues. In the case of innovative and growth-oriented SMEs, during the years prior to the 2008 global financial crisis, it was relatively harder for innovative firms to access bank capital than for non-innovative firms (Lee et al., 2015). In the post-crisis years, after controlling for Heckman-selection effects, it became clear that the difficulties for innovative firms to access capital have increased, but the difficulties faced by non-innovative firms have increased even further (Lee et al., 2015). The persistent difficulties faced by innovative firms in accessing bank capital are a structural feature, whereas the increased difficulties faced by non-innovative firms are a cyclical feature (Lee et al., 2015). 
There is also evidence suggesting that there are clear regional differences in credit availability for these key sectors of the market (Hutton and Lee, 2012). Obviously, self-selection and self-sorting suggests that differences in the regional availability of credit are likely to be heavily shaped by the regional economic structure, the buoyancy of the region, and other endogenous factors, but until recently spatial and regional issues have been largely neglected in the literature on the financing of SMEs (Ughetto et al., 2019). Now, however, it is becoming clear that there are persistent local and regional differences in credit availability, and especially for the critical cohort of dynamic SMEs and start-up, even after controlling for each of these issues.

In the UK, distance appears to be a clear liability for SME short-term credit funding even after controlling for all other firm-specific and region-specific features which may influence latent risk, and this penalty for peripherality is primarily associated not with access to credit, but with the pricing of credit (Cowling et al., 2019). In the aftermath of the 2008 global financial crisis, after controlling for any Heckman-selection bias, difficulties regarding SMEs' access to bank finance were found to be greater the larger the functional distance between a bank's headquarters and its branches (Zhao and Jones-Evans, 2017). Using probit models and also controlling for selection effects (Lee and Brown, 2017), it becomes clear that even innovative firms in geographically peripheral areas are more likely to be discouraged from applying for bank finance because they are more likely to have their applications rejected, relative to more centrally located firms (Lee and Brown, 2017). In order to respond to these gaps, SMEs in the UK's more peripheral regions use credit cards to a greater extent to fill financial gaps than SMEs in core locations (Brown et al., 2019a). This is also generally the case for innovative, growth-oriented, and export-oriented firms and these same firms which use credit cards to plug financial gaps are also more likely subsequently to seek additional funding sources (Brown et al., 2019a). Therefore, finding ways to ensure that the UK domestic banking system is more diversified, more regionally balanced, and providing more of a focus on innovation-oriented, growth-oriented, and export-oriented long-term investment rather than short-term profits and financial engineering is essential (Hutton and Lee, 2012). There is something of an urgency here in that recent UK evidence finds that it is the more dynamic innovation-oriented, growth-oriented, and trade-oriented elements of the UK SME landscape which are the most concerned about Brexit and those same firms which are scaling back the most on investment plans (Brown et al., 2019b). 
The international and UK-specific evidence reported here suggests that the evolved structure of, and also recent changes to, the UK banking sector, are indeed likely to be a key element in the interregional inequalities in business credit which we observe, and especially those credit lines which are needed by the innovative, growth-oriented, and export-oriented SME firms which we know are so critical to the overall performance of the UK economy. As a result, they are likely to be a key part of the explanation as to why the UK exhibits such profound interregional differences in productivity performance. This raises the question as to what role these issues, and the possible policy responses to these issues, may play in the current 'levelling up' challenges.

\section{Three examples of relationship banking}

Finding ways to promote advantageous banking reforms in the UK to facilitate the long-term 'levelling up' of the UK economy would appear to be a key challenge for promoting national productivity growth (McCann and Vorley, 2020) and clues as to how this might be approached can be found by considering evidence from other countries. The three illustrative examples we consider here are the banking systems of Germany, the community banking system of the USA, and also the firm-specific example of the Swedish bank, Handelsbanken.

\section{(i) The German banking system}

Important insights can be gained by consideration of the German banking system. The German financial system is similar to the Japanese banking system in that it is very much a bank-dominated system in which most finance is intermediated through the banking sector rather than through capital markets (Allen and Gale, 1995, 2001; La Porta et al., 2000; Heffernan, 2004). It is a system in which the relations between banks and commercial customers are typically stronger than is generally found in most other parts of the world (Elsas and Krahnen, 1998; Hackethal, 2004; Krahnen and Elsas, 2004). 
The German banking system has been characterized as a 'Three Pillar Banking System' in which there are three categories of bank operating, namely private banks, savings banks, and cooperative banks. These three types of bank are distinguished from one another by virtue of where they are permitted to operate in the German state as well as their unique ownership and legal characteristics. Private banks are the first pillar of the German banking system. Private banks consist of any and all commercial banks that are privately owned and have corporate structures that allow for private ownership (Behr and Schmidt, 2016). Private banks have a corporate structure and business focus that is similar to the private banks in the UK; they have private ownership and have the main goal of maximizing profit for shareholders. Moreover, the private nature of these banks allows them to operate with few regional or geographical restrictions. As of January 2020, the large private banks consist of Deutsche Bank AG, Commerzbank AG, UniCreditbank AG, and DB Privat-und Firmenkundenbank AG (see Deutsche Bundesbank, 2020). ${ }^{1}$

The second pillar of the banking system is the savings banks. ${ }^{2}$ There are two sub-categories of savings banks: the Sparkassen and the Landesbanken. As of 2020, over 400+ Sparkassen and 7 Landesbanken currently operate in Germany (Flögel, 2018; Deutsche Bundesbank, 2020). Savings banks are quasi-public enterprises that operate under a public law regime with legal constraints on their operations in accordance with German law. Savings banks are characterized as having unique ownership; a mix of private and public ownership. Coupled with specific savings bank laws, these constraints shape the goal of savings banks not to maximize profit but to provide their designated regions with banking services as efficiently and profitably as possible (Hackethal, 2004). Savings banks are obliged to place branches only within the area of their authority and to lend first to commercial, household, and institutional customers in that area (Flögel, 2018). Thus, savings banks are akin to decentralized banks as defined in this study, in that they are geographically bounded and operate so as to provide regionally based customers with banking services in a trustlike manner.

\footnotetext{
${ }^{1}$ According to the Bundesbank, two categories of private banks consist of 'large banks' and 'regional and other commercial' banks.

${ }^{2}$ Some studies identify these as state-owned banks. We elect to use the term savings banks to emphasize their specific business and local focus rather than their ownership.
} 
Sparkassen and Landesbanken have also banded together to promote their interests and protect their local operations through a number of associations. Some Sparkassen and Landesbanken are members of the Association of German Public Sector Banks (Bundesverband Öffentlicher Banken Deutschlands - VÖB). Most of the Sparkassen and Landesbanken are represented by the German Savings Banks Association (Deutscher Sparkassen-und Giroverband-DSGV). Both of these associations provide savings banks with representation in the government as an advocacy group and establish strategic direction for both banks.

Meanwhile, the third pillar of the german banking system is the cooperative banks. These banks are cooperatives that are engaged in providing banking services for their members but, like other cooperative institutions, these institutions are structured as 'clubs' that have a membership system. The services offered by these cooperative banks are given exclusively to their members with their corporate purpose focused explicitly on supporting members. As of January 2020, there are over 1,000 of these institutions operating throughout Germany (Deutsche Bundesbank, 2020).

The three-pillar banking system in Germany emerged as a direct consequence of the push to rapidly develop the German economy in its early history. To assist the development of SMEs and agriculture, the Sparkassen were established in the early 1800s. The Landesbanken emerged in the 1830s to provide investment facilities and support Sparkassen at the regional level, and the Landesbanken followed suit in facilitating local and regional development while expanding the types of business facilities on offer (Detzer et al., 2013). Private and cooperative banks emerged in the late 1850s, with the former assisting the establishment of joint stock companies and providing capital to allow such companies to achieve rapid growth, while the latter expanded with the rise of the cooperative movement (Gerschenkron, 1962; Feldenkirchen, 1991; Detzer et al., 2013). Overall, the German banking system was focused on developing the economy through the marshalling of financial resources at all administrative divisions of the German state.

In terms of the provision of relationship banking, it is the Sparkassen and Landesbanken which are critical. Sparkassen are savings banks that are small to medium in size, and legally focused on providing services to designated municipalities and counties. As a decentralized bank, their focus is on supporting the development of the economy where they are regionally bound, which is 
typically done through close relationships with the local businesses they lend funds to. Sparkassen are noted for having a unique ownership structure. While they are commonly cited as 'state owned', Behr and Schmidt (2016) argue that it is better to view their ownership as 'being supported by one or more respective municipalities'. This is because the ownership stakes that one or more state organs take in a Sparkassen are constrained. More often than not, the state has limited property rights as well as lower legal obligations than are typically given to shareholders in companies limited by shares. In some instances, the benefits of ownership are even legally required to be put into local projects or opportunities should they arise (Behr and Schmidt, 2016).

Previous research has noted the importance of the Sparkassen to the local German economies. Roughly 99 per cent of all German businesses are SMEs which typically makes financing via capital markets infeasible (Simpson, 2013). The Sparkassen meet this funding need by acting as the 'Hausbank' for their respective municipalities. Consumers, as well, have directly benefited from the operations of Sparkassen with roughly half of all German bank customers having an account with one (Simpson, 2013). Empirical research by Behr et al. (2013) confirmed that Sparkassen reduce the financial constraints of SMEs by 3-10 per cent, and they play a critical role when soft information is most critically required regarding credit decisions for struggling SMEs (Flögel, 2018).

Further underscoring the importance of the Sparkassen are their role and performance during the 2009 financial crisis. Sparkassen were used to inject funds into local labour and businesses quickly so as to mitigate the effects of the crisis while ensuring that both firms and employees were equally sheltered from the recession (Simpson, 2013). In the years since the crisis, Spakassen have maintained strong credit ratings and have been highlighted as some of the most financially stable banks currently operating in Germany.

Meanwhile, Landesbanken are larger, regionally focused savings banks. Smaller than the private banks but still quite large, these banks are tasked with servicing customers in their designated regions within the German state. These tasks include providing universal banking services to their designated state, supporting Sparkassen in the region by acting as a regional central bank and clearing institution, and serving as a general Hausbank for their designated state. 
Landesbanken vary, even among themselves, in terms of their legal and organizational form. Some take legal forms regulated by public law, while others are structured as companies limited by shares. In terms of ownership they may be state-owned, private, or uniquely constructed in accordance with German law. Most are owned partially by the German state of location, by other Landesbanks, and/or by regional Sparkassen (Hackethal, 2004).

In more recent years, the Landesbanken have faced some significant challenges. The strong connection between the Landesbanken and German states came under scrutiny with EU competition and state aid regulations and, in 2001, an agreement was reached in order to weaken the link between the Landesbanken and the state and to promote more competition in the banking sector. This reform led to the Landesbanken expanding their business activities significantly into international banking and investment banking in the following years. Consequently, when the global financial crisis hit in 2008, many Landesbanken were also exposed to the types of toxic assets that caused crises in the banking sector. To resolve the problems, many Landesbanken were recapitalized and forced to merge.

While financial re-regulation and consolidation in the aftermath of the 2008 crisis drove centripetal forces within both the British and German national banking systems (Wójcik and MacDonaldKorth, 2015), the outcomes were very different because the German decentralized banking system responded to the crisis in very different ways to the UK system. As both systems absorbed the shocks, in the UK this led to much greater organizational and spatial concentration, with only London gaining, whereas in Germany the decentralized system saw no spatial concentration whatsoever (Wójcik and MacDonald-Korth, 2015).

Moreover, empirical research has shown the structure of the German banking system to provide more credit to regional and local SMEs than the UK both before and after the financial crisis. Klagge et al. (2017) show that since 1989, the number of bank branches in the UK has been reduced from 12,000 to 9,500 , reducing the density of banks from 150 per million population compared to 450 in Germany. Work by Degryse et al. (2018) has shown that bank lending to manufacturing SMEs in the British regions over 2004-11 was severely affected by increasing 
distance between the banks and their customers, suggesting significant credit was effectively rationed to areas where banks were located, rather than regions where they did not operate. In contrast, the Deutsche Bundesbank (2015) showed that, in 2014, 40 per cent of all credit extended to SMEs was by savings and cooperative banks. Gärtner and Flögel (2013) find that this large role is primarily due to differences in decision-making criteria for credit provision that such banks have, which explains why they have a leading role in financing SMEs. Moreover, Gärtner and Flögel (2014) find that savings and cooperative banks increased their overall credit volumes since 2007, which has been argued to have provided stabilization to both the German economy and its SME sector during the crisis (Gärtner, 2011).

\section{(ii) The US community banking system}

The second example of relationship banking we consider is that of the US community banking system. Historically, the institutional and political structure of the USA has led to a strong division between national and state-level governance that is similarly reflected in its banking system. Banks are chartered at either the national or state level. National banks are permitted to operate across state lines and are also required by law to be members of the Federal Reserve System. In contrast, state-chartered banks are primarily regulated by the banking regulator of the state in which they are located. A state bank may come to be regulated by the Federal Reserve Board if it elects to be a member of the Federal Reserve System; but if not, then the bank is required to become a member of the Federal Deposit Insurance Corporation (FDIC).

A common type of decentralized bank that operates within the USA is community banks. There are currently close to 5,000 community banks in the US which specialize in banking for local SMEs and family businesses. These community banks account for some 40 per cent of small loans to business (The Economist, 2019). Traditionally these banks have been defined as banking institutions that possess less than $\$ 1$ billion in assets, although in 2010 the FDIC expanded the definition to include banks that are indexed to $\$ 10$ billion in assets as of 2010, have a specific composition of assets and liabilities that are more weighted to lending and deposit products, and 
have a specific number of offices where they are located. ${ }^{3}$ The FDIC also notes that community banks stress decentralized banking activities as their core business strategy: relationship lending.

In 2015, community banks accounted for 93 per cent of all banks and 13 per cent of all banking assets in 2015. In 2012, the FDIC found that non-community banks reported higher yields and lower loan losses compared with non-community banks, with significant advantages coming from higher net interest income and lower credit losses (FDIC, 2012). In more recent years, it has been shown that community bank core profitability has recovered from the sharp decline caused by the financial crisis in 2008 and has reached levels that are consistent with its historical performance of around 1 per cent return on assets (FDIC, 2016). As of the second quarter 2019, community banks reported a net income of $\$ 6.9$ billion; a 8.1 per cent increase in net income from the previous year (FDIC, 2019).

However, in recent years, there have been notable trends suggesting fundamental changes in the community banking space. In 2012, the FDIC found that non-community banks were able to generate higher levels of non-interest income and thus a comparatively better efficiency ratio, noninterest expense to net operating revenue. In response, community banks were further shown to be altering their lending profiles to be more commercially rather than residentially oriented (FDIC, 2012). Moreover, further significant merger activity has reduced community banks from a high of 15,957 community banks to 5,874 in 2015 and to 4,874 as of second quarter 2019 (FDIC, 2019).

The Federal Deposit Insurance Corporation (FDIC) is also an important aspect of decentralized banking in the US. While it is not a bank itself, the FDIC plays a large role in promoting the viability of smaller community and locally based banks in the USA through the provision of insurance, regulatory, and receivership services to state banks as a federal agency. The FDIC has a regulatory role in the US banking system as both an insurer and a regulator that ensures a level of standardization in regulation between state-chartered banks. FDIC member banks are able to provide full insurance on a depositor's account up to a value of $\$ 250,000$ as of 2008 , and this insurance scheme is funded from contributions of member banks and other funding sources. In addition to this role, the FDIC is charged with supervision and receivership roles. The FDIC is

\footnotetext{
${ }^{3}$ See FDIC (2012) for a full discussion of this approach
} 
required to examine and supervise financial institutions for safety and soundness as well as ensure that consumers' rights are protected. Moreover, the FDIC is granted powers to ensure that insolvent financial institutions are efficiently wound up and to manage receivership of a failing banking institution in an effective way.

In the years since its establishment, the FDIC has had to deal with two major systemic events: the savings and loans crisis of the 1980s and the financial crisis of 2008. In the former case, savings and loans institutions ran into financial difficulties as deposit rates were set significantly higher than the 30-year mortgage lending rate that they relied upon for income. To meet the gap, lending and capital standards were relaxed with many investing in speculative land projects that did not succeed. To resolve the problem, the FDIC was given expanded powers by congress to allow for direct intervention and assistance to resolve the problem. ${ }^{4}$ In the financial crisis of 2008 , the FDIC similarly acted in its capacity as both a receiver in the winding up of Washington Mutual Bank and to provide the bank Wachovia with assistance during the height of the crisis. As in the savings and loans crisis, the FDIC was granted additional powers to handle all systemically important financial institutions in the face of a crisis in accordance with the 2010 Dodd-Frank Act.

Although it is under threat from the centralized banking system, the decentralized relationshipbased local community banking system of the USA still provides ongoing critical lifelines to those parts of the US commercial landscape, and especially SMEs and weaker localities, which are typically disadvantaged by the centralized national banking systems.

\section{(iii) Handelsbanken}

The third example we consider is that of the Swedish bank Handelsbanken. Founded initially in 1871, Handelsbanken is one of the largest banks in Sweden. As of 2019, the bank had a total market capitalization of 191 billion SEK, making the bank one of the top 50 largest banks in Europe. The bank was also one of the highest credit-rated global banks according to Fitch, Moody's, and Standard and Poor's in 2019 (Handelsbanken, 2020). Moreover, the bank has over

\footnotetext{
${ }^{4}$ See Bovenzi (2015) for a more extensive discussion of the actions of the FDIC during this period.
} 
750 branches across the Nordic countries, the Netherlands, and the UK, where a considerable focus has been paid on expanding operations in recent years (Handelsbanken, 2020).

As an institution, Handelsbanken has adopted a decentralized institutional structure and operational approach. According to Kroner (2011), the bank adopts a strategy of 'the Branch is the Bank', in which individual branches are seen as being the main way banking services are delivered. Institutionally, Handelsbanken has arranged itself to give individual branches within the bank an enormous amount of autonomy over their operations (Larsen et al., 2014). Branches are able individually to dictate inter alia, prices of their financial products, their approach to marketing their products, and customer segmentation policies.

The idea behind this approach is to allow the bank to become as locally based as possible, and it is able to flexibly arrange itself so as to best suit the area within which it operates. The head office acts to coordinate overall bank activities but not to prevent local branches from establishing their general approach. To further stress the importance of locality, Handelsbanken sets strict geographical divisions between branches so as to prevent business cannibalization and to define what region the branch should focus on.

Handelsbanken focuses on establishing strong customer relationships. The bank emphasizes the importance of both forming and maintaining clients through strong person-to-person contact. This is done through direct meetings with clients as well as open communication strategies. Moreover, individual branches are often allowed to meet the specific needs of their customers due to the power of branches to set their own policies. Handelsbanken is notable for its financial success while maintaining its decentralized structure. The bank has been able to provide a return on equity of between 15 and 10 per cent since the turn of the millennium, it was able to navigate the financial crisis of 2008 with little difficulty, and it significantly outperformed its peers in the process (Kroner, 2011). The bank credits its survival and success to both its business approach as well as to its focus on risk management and control (Kroner, 2011).

The feature of the Handelsbanken example is that well-executed relationship banking can be highly profitable and stable precisely because it is so embedded in the local context. 


\section{Discussion}

If we reconsider the wide range of UK and international empirical evidence presented in this paper in the light of the three relationship banking examples outlined here, the deficiencies of the UK banking systems become starkly apparent. Apart from Handelsbanken, the UK exhibits effectively no relationship banking system of a type that still flourishes in Germany and the US. The highly centralized UK banking system disadvantages SMEs, and especially those firms in more peripheral regions, almost exactly in accordance with what the international evidence would predict (Klagge and Martin, 2005; Alessandrini et al., 2009; Klagge et al., 2017). Therefore, in order to address the enormous levelling-up challenges facing the UK, in the light of the empirical evidence reviewed in this paper, these US, German, and Swedish examples of relationship banking provide three broad lessons for the UK, namely: (i) promote decentralized banking at the regional and local level; (ii) utilize both law and organizational form to direct corporate purpose; and (iii) a strong link between the state and the bank could produce problems.

On the first point regarding the need to promote decentralized banking at the regional and local levels, much like the US, the German banking system is defined by how the overall country is administratively divided. What is unique in the German case, however, is how decentralized banking specifically can be found at all levels. The Sparkassen provide all manner of banking services at the very local level, while the Landesbanken not only support the Sparkassen in doing so, but also offer larger financial products and services when benefits of scale are needed. This structure essentially allows firms to have access to financing outside of markets through all phases of a company's growth cycle. Yet, there is no reason to assume that these more decentralized forms of relationship banking are bad for competition and efficiency. Indeed, the experience of the German banking sector and the division between national and local decentralized banks suggests that decentralized banks operating at different scales operate not in competition with each other but, rather, service distinctly different customers. This raises the prospect that decentralized banking sectors may be able to provide financing to all levels of firms from SMEs to larger regional and/or nationally bound businesses. 
On the second point regarding the need to utilize both law and organizational form to direct corporate purpose, the insights from the German and US cases is that the institutional structure governing the operations of both the Sparkassen and Landsbanken and the US community banks ensures a decentralized local focus. For example, savings banks are required, under law, to provide universal banking services to their designated region with the explicit goal to serve regional development. Such requirements are further reinforced within the constitutions of the savings banks as well. Similarly, US community banks are almost entirely focused on the local provision of services to local customers, many of which are those same commercial customers who are largely disadvantaged or even excluded by the centralized banking systems. Moreover, the German approach also illustrates the importance of using ownership structures to direct the corporate purpose of decentralized banks towards policy goals. Savings banks adopt ownership structures that blend private and public ownership of the region they operate within, and this provides the firms with shareholders who direct the company towards profitability while also providing a local focus to their activities. Handelsbanken also provides a further illustration of the importance of the role of organizational structure to drive decentralization. Granting individual branches significant power allows them to establish a local presence through flexibility, and this approach can only be adopted so long as the overall bank commits to having a structure to facilitate such operations.

Another feature of relationship banking is the ability to promote decentralized banking in order to help to mitigate systemic risk. German decentralized banks have shown policy-makers a potentially novel way to reduce the effect of financial crises, in that Sparkassen were a vital component in the German response to the 2008 financial crisis. By being able to inject funds into local labour markets and businesses during a time of crisis, Germany was able to mitigate the severity of its effects on the local German economy. These advantages may again prove to be a crucial advantage in the current coronavirus crisis: in particular, maximizing the resilience of Germany's SME and Mittelstand sectors, especially in the regions most vulnerable to the crisis.

On the third point regarding the fact that strong links between state and bank could produce problems, from the German experience, it is also important to note that decentralized banking may also have risks that should be addressed. The experience of the Landesbanken in particular shows 
that decentralized banks may become prone to excessive risk-taking, even if they are regionally constrained in their operations. Strong regional control and potential ownership through public means may present further incentives to engage in risky behaviour through soft-budget constraints and moral hazard problems as well. Yet, the experience of the Sparkassen compared to the Landesbanken suggests that there are ways to address this. The heavy regulation that limited Sparkassen from adopting more risky products and activities ensured that such banks were able to avoid many of the problems that the Landesbanken experienced. On the one hand, this therefore suggests that in order to be effective, decentralized banking may need to be more heavily regulated and administered than other banking entities so as to ensure such behaviour is avoided. On the other hand, excessive deregulation can potentially lead to a reduction in decentralized banking. The extensive deregulation of the banking industry in the US has been shown to have resulted in significant reduction in community banks and greater interregional difficulties of credit access for local SMEs and for businesses in weaker regions. Germany, by contrast, has still maintained a significant amount of regulation in the banking system and has witnessed far less consolidation, and far lower interregional inequalities. Striking an appropriate balance may be the main issue in this regard.

\section{Conclusions}

In the case of the UK 'levelling up' agenda, the evidence reviewed here suggests that it is possible that decentralized banking in the UK could be promoted as a way to provide fundamental banking services to those sectors and regions which are adversely affected by the highly centralized systems we currently exhibit. There is now a growing awareness of these issues (Sensier, 2017; Singh et al., 2020), the importance of which has been very recently underscored by the fact that local relationship banking has been seen to be more effective than corporate banking in maintaining government-backed credit lines for SMEs during the Covid-19 crisis (Mitchell, 2020a,b). Having a network of decentralized banks providing essential local banking services could therefore provide UK policy-makers with a way to insure local regions against financial crises and maintain consistent access to funds during such events. However, to do this the German and US cases suggest that UK policy-makers seeking to promote decentralized banking may need to provide 
more regulatory protections to decentralized banks than has commonly been advocated by policymakers in more recent times.

Policy-makers in the UK could promote the creation of model decentralized bank Articles of Association that emphasize similar themes of decentralization and regional development in their operations. Moreover, a policy to promote diverse, local ownership should also be incentivized. This should allow the bank not only to access better long-term relationship-based regional knowledge, but also provide a powerful voice to direct the bank to keep its operations in local areas. Moreover, a network of decentralized banks could also allow for a national regulator to conduct more targeted regulatory oversight over credit markets in a region. The FDIC is a good example of a national regulator that can effectively regulate local credit markets through targeted regulation of community banks. This may allow policy-makers and governments to better detect issues in local credit markets and to respond appropriately if conditions deteriorate.

Such initiatives could be especially important for local SME and family-business sectors. For the SME segments of the market, there are some possible policy options. In the US, there is a positive relationship between local employment and the local levels of Small Business Administrationguaranteed lending (Craig et al., 2008), primarily in low-income markets, so similar types of schemes in the UK may be useful if allied with more decentralized banking systems. In the UK the only institution currently operating in this space is the British Business Bank (BBB) which was set up in 2014 to play a partial role in acting as an intermediary channelling funds to local markets, and the remit of the BBB was only recently changed in 2018-19 to include the identification and reduction of regional imbalances in access to finance for UK SMEs (NAO, 2020). While early evidence of the BBB is encouraging (NAO, 2020), it is still far too small, too recent, and its remit is still too undefined for its performance in the interregional levelling-up of UK SME finance to be assessed. More importantly, the BBB has no real relationship banking capability, the key missing element in most of the UK banking system. In addition to the BBB, the UK has sought to address the high level of concentration of its banking system through encouraging the entry of new 'challenger' banks. But as a House of Commons Treasury Committee (2018) records: 'While the emergence of new entrants is welcome, by the Government's own admission, more work is needed to bring meaningful competition that will improve outcomes for SMEs.' 
The weaknesses in the UK banking system which these relationship banking discussions here have highlighted, also relate to the public and civil-society sectors, as well as the private sector. For wider local markets, including those for major public investments in infrastructure, public R\&D, and skills training programmes, larger-scale financial interventions will be required, not all of which can be provided centrally. As city-regions, and indeed many parts of the whole institutional fabric of the UK governance system, move towards greater levels of devolution, over the coming years it will be the case that greater financial capability will be required in the newly evolving and more locally-oriented governance bodies (Pike et al., 2019). This is especially so in the case of cities located in the weaker regions of the UK because the long-run investment needs of these localities are greater than in the more prosperous regions while at the same time their local tax bases are weaker (Pike et al., 2019). Although many sub-national bodies already have the legal powers to do so, in reality the vast majority of UK sub-national government institutions have not in any significant way sought to access the international financial markets independently of central government (Pike et al., 2019), in a manner which is common in federal systems such as Germany and the USA. However, as devolution proceeds in the coming years, the pressures to do so will increase, as will the need to develop greater local sophistication in financial skills and management both for negotiating and managing relations with domestic and international sources of capital as well as with HM Treasury. This will require more sophisticated, but also much more locallyrooted, long-term financial relationships, and these can only be developed if the local banking system is also more locally-embedded, locally-knowledgeable, and also more long-term in its financial relations, as is the case in the relationship banking systems in countries such as Germany and USA, and also in Japan and the Nordic countries. The highly centralized UK banking system is currently poorly designed and poorly equipped to foster the types of local financial relations and capabilities relationships which will be necessary to ensure that both devolution and levelling up are successful in the long run. 


\section{References}

Agarwal, S., and Hauswald, R. (2010), 'Distance and Private Information in Lending', Review of Financial Studies, 23, 2757-88.

Agarwal, S., Chomsisengphet, S., Liu, C., Song, C., and Souleles, N.S. (2018), 'Benefits of Relationship Banking: Evidence from Consumer Credit Markets', Journal of Monetary Economics, 96, 16-32.

Aguirregabiria, V, Clark, R., and and Wang, H. (2019), 'The Geographic Flow of Bank Funding and Access to Credit: Branch Networks, Local Synergies, and Competition', CEPR Discussion Paper DP13741, Centre for Economic Policy Research, London.

Alessandrini, P., Croci, M., and Zazzaro, A. (2005), 'The Geography of Banking Power: The Role of Functional Distance', Banca Nazionale del Lavoro Quarterly Review, 58, 129.

Alessandrini, P., Presbitero, A. F., and Zazzaro, A. (2009), 'Banks, Distances and Firms' Financing Constraints', Review of Finance, 13, 261-307.

Alessandrini, P., Presbitero, A. F., and Zazzaro, A. (2010), 'Bank Size or Distance: What Hampers Innovation Adoption by SME?', Journal of Economic Geography, 10, 845-81.

Allen, F., and Gale, D. (1995), 'A Welfare Comparison of Intermediaries and Financial Markets in Germany and the US', European Economic Review, 39(2), 179-209.

Allen, F., and Gale, D. (2001), 'Comparative Financial Systems: A Survey', Working Paper, Wharton School, Philadelphia, PA, University of Pennsylvania.

Beck, T., Levine, R., and Levkov, A. (2010), 'Big Bad Banks? The Winners and Losers from Bank Deregulation in the United States', The Journal of Finance, 65(5), 1637-67.

Becketti, S., and Morris, C. (1992), ‘Are Bank Loans Still Special?’, Economic Review-Federal Reserve Bank of Kansas City, 77, 71-1.

Behr, P., and Schmidt, R. H. (2016), 'The German Banking System', in The Palgrave Handbook of European Banking, Palgrave Macmillan, 541-66.

Behr, P., Norden, L., and Noth, F. (2013), 'Financial Constraints of Private Firms and Bank Lending Behavior', Journal of Banking and Finance, 37, 3472-85.

Belluci, A., Borosiv, A., and Zazzaro, A. (2014), 'Do Banks Price Discriminate Spatially? Evidence from Small Business Lending in Local Credit Markets', Journal of Banking and Finance, 37, 4183-97. 
Bellucci, A., Borisov, A., Giombini, G., and Zazzaro, A. (2019), 'Collateralization and Distance', Journal of Banking \& Finance, 100, 205-17.

Berger, A. N., and Udell, G. F. (1995), 'Relationship Lending and Lines of Credit in Small Firm Finance', The Journal of Business, $\mathbf{6 8}, 351$.

Berger, A. N., and Udell, G. F. (2002), 'Small Business Credit Availability and Relationship Lending: The Importance of Bank Organisational Structure', The Economic Journal, 112, F32-F53.

Berger, A. N., Hasan, I., and Klapper, L. F. (2004), 'Further Evidence on the Link between Finance and Growth: An International Analysis of Community Banking and Economic Performance', Journal of Financial Services Research, 25, 169-202.

Berger, A. N., Klapper, L. F., and Turk-Ariss, R. (2017), 'Bank Competition and Financial Stability', Handbook of Competition in Banking and Finance, Edward Elgar.

Boot, A. W. A. (2000), 'Relationship Banking: What Do We Know?', Journal of Financial Intermediation, 9, 7-25.

Boot, A. W. A., and Thakor, A.V. (1994), 'Moral Hazard and Secured Lending in an Infinitely Repeated Credit Market Game', International Economic Review, 35, 899.

Bovenzi, J. F. (2015), Inside the FDIC, John Wiley \& Sons.

Boyd, J. H., and Gertler, M. (1993), 'US Commercial Banking: Trends, Cycles, and Policy', NBER Macroeconomics Annual, 8, 319-68.

Boyd, J. H., and Gertler, M. (1995), ‘Are Banks Dead? Or are the Reports Greatly Exaggerated?', National Bureau of Economic Research.

Brown, R., Liñares-Zegarra, J., and Wilson, J. O. S. (2019a), 'Sticking it on Plastic: Credit Card Finance and Small and Medium-sized Enterprises in the UK', Regional Studies, 53(5), $630-43$.

Brown, R., Liñares-Zegarra, J., and Wilson, J. O. S. (2019b), 'The (Potential) Impact of Brexit on UK SMEs: Regional Evidence and Public Policy Implications', Regional Studies, 53(5), $761-70$.

Canales, R., and Nanda, R. (2012), 'A Darker Side to Decentralized Banks: Market Power and Credit Rationing in SME Lending', Journal of Financial Economics, 105, 353-66. 
Conroy, T., Low, S. A., and Weiler, S. (2017), 'Fuelling Job Engines: Impacts of Small Business Loans on Establishment Births in Metropolitan and Nonmetro Counties', Contemporary Economic Policy, 35, 578-95.

Cowling, M., Lee, N., and Ughetto, E. (2019), 'The Price of a Disadvantaged Location: Regional Variation in the Price and Supply of Short-term Credit to SMEs in the UK', Journal of Small Business Management, see: https://doi.org/10.1080/00472778.2019.1681195

Craig, B. R., Jackson, W. E., and Thomson, J. B. (2008), 'Credit Market Failure Intervention: Do Government Sponsored Small Business Credit Programs Enrich Poorer Areas?', Small Business Economics, 30, 345-60.

Crocco, M., Faria-Silva, F., Paulo-Rezende, L., and Rodríguez-Fuentes, C. J. (2014), 'Banks and Regional Development: An Empirical Analysis on the Determinants of Credit Availability in Brazilian Regions', Regional Studies, 48(5), 883-95.

Degryse, H., and Ongena, S. (2005), 'Distance, Lending Relationships, and Competition', The Journal of Finance, 60, 231-66.

Degryse, H., Matthews, K., and Zhao, T. (2018), 'SMEs and Access to Bank Credit: Evidence on the Regional Propagation of the Financial Crisis in the UK', Journal of Financial Stability, 38, 53-70.

Detzer, D., Dodig, N., Evans, T., Hein, E., and Herr, H. (2013), 'Studies in Financial Systems No 3 The German Financial System', FESSUD Studies, Financialisation, Economy, Society \& Sustainable Development (FESSUD) Project.

Deutsche Bundesbank (2015), Bankenstatistik August 2015, Statistisches Beiheft 1 zum Monatsbericht, Frankfurt, Deutsche Bundesbank, retrieved on 17 July 2020 from https://www.bundesbank.de/resource/blob/693952/921e5b1187bcaad370e0d5be1338ffa3/ $\underline{\mathrm{mL} / 2015-11 \text {-bankenstatistik-data.pdf }}$

Deutsche Bundesbank (2020), Bankenstatistik March 2020, Statistisches Beiheft 1 zum Monatsbericht. Frankfurt, Deutsche Bundesbank, retrieved on 14 October 2020 from https://www.bundesbank.de/resource/blob/828478/f43932d18d26295d3bd449ef58ab0108 /mL/2020-03-bankenstatistik-data.pdf

Elsas, R., and Krahnen, J. P. (1998), 'Is Relationship Lending Special? Evidence from Credit-file Data in Germany', Journal of Banking \& Finance, 22, 1283-316.

FDIC (2012), FDIC Community Banking Study, Federal Deposit Insurance Corporation. 
FDIC (2016), 'Core Profitability of Community Banks, 1985-2015', Federal Deposit Insurance Corporation, retrieved on 14 October 2020 from https://www.fdic.gov/bank/analytical/quarterly/2016-vol10-4/article1.pdf

FDIC (2019), ‘2019 Summary of Deposits Highlights', Federal Deposit Insurance Corporation, retrieved on 14 October 2020 from https://www.fdic.gov/bank/analytical/quarterly/2020vol14-1/fdic-v14n1-4q2019-article.pdf

Feldenkirchen, W. (1991), Das Jahrbuch für Wirtschaftsgeschichte, VSWG: Vierteljahrschrift für Sozial-und Wirtschaftsgeschichte, 78, 532-48.

Flögel, F. (2018), 'Distance and Modern Banks' Lending to SMEs: Ethnographic Insights from a Comparison of Regional and Large Banks in Germany', Journal of Economic Geography, 18(1), 35-57.

Gärtner, S. (2011), 'Regionen und Banken: Gedanken im Lichte der Krise', Informationen zur Raumentwicklung, 2, 153-67.

Gärtner, S., and Flögel, F. (2013), 'Dezentrale vs. zentrale Bankensysteme? Geographische Marktorientierung und Ort der Entscheidungsfindung als Dimensionen zur Klassifikation von Bankensystemen', Zeitschrift für Wirtschaftsgeographie, 57(3), 105-21.

Gärtner, S., and Flögel, F. (2014), 'Call for a Spatial Classification of Banking Systems through the Lens of SME Finance-Decentralized versus Centralized Banking in Germany as an Example', EconStor Preprints 97512, ZBW—Leibniz Information Centre for Economics.

Gerschenkron, A. (1962), Economic Backwardness in Historical Perspective: A Book of Essays, Cambridge, MA, Belknap Press of Harvard University Press.

Gertler, M. S. (2005), 'Tacit Knowledge and the Economic Geography of Context, or the Undefinable Tacitness of Being (There)', Journal of Economic Geography, 3(1), 75-99.

Gobbi, G., and Sette, E. (2014), 'Do Firms Benefit from Concentrating their Borrowing? Evidence from the Great Recession', Review of Finance, 18(2), 527-60.

Goetz, M. R., Laeven, L., and Levine, R. (2016), 'Does the Geographic Expansion of Banks Reduce Risk?', Journal of Financial Economics, 120(2), 346-62.

Grilli, L. (2019), 'There Must be an Angel? Local Financial Markets, Business Angels and the Financing of Innovative Start-Ups', Regional Studies, 53(5), 620-9.

Hackethal, A. (2004), 'German Banks and Banking Structure', in The German Financial System, Oxford, Oxford University Press, 71-105. 
Handelsbanken (2020), Annual Report 2019.

Hasan, I., Jackowicz, K., Kowalewski, O., and Kozłowski, T. (2019), 'The Economic Impact of Changes in Local Bank Presence', Regional Studies, 53(5), 644-56.

Hauswald, R., and Marquez, R. (2006), 'Competition and Strategic Information Acquisition in Credit Markets', Review of Financial Studies, 19, 967-1000.

Heffernan, S. (2004), Modern Banking, Chichester, John Wiley \& Sons.

House of Commons Treasury Committee (2018), SME Finance, Twenty-fourth Report of Session 2017-19.

Hutton, W., and Lee, N. (2012), 'The City and the Cities: Ownership, Finance and the Geography of Recovery', Cambridge Journal of Regions, Economy and Society, 5, 325-37.

Iyer, R., Peydró, J.-L., da-Rocha-Lopes, S., and Schoar, A. (2014), 'Interbank Liquidity Crunch and the Firm Credit Crunch: Evidence from the 2007-2009 Crisis', The Review of Financial Studies, 27(1), 347-72.

Jiménez, G., Salas, V., and Saurina, J. (2009), ‘Organizational Distance and Use of Collateral for Business Loans', Journal of Banking \& Finance, 33, 234-43.

Jiménez, G., Ongena, S., Peydró, J. L., and Saurina, J. (2012), ‘Credit Supply and Monetary Policy: Identifying the Bank Balance-sheet Channel with Loan Applications', American Economic Review, 102(5), 2301-26.

Kay, J. (2016), Other People's Money, Profile Books.

Klagge, B., and Martin, R. (2005), 'Decentralized versus Centralized Financial Systems: Is There a Case for Local Capital Markets?', Journal of Economic Geography, 5, 387-421.

Klagge, B., Martin, R., Sunley, P., et al. (2017), 'The Spatial Structure of the Financial System and the Funding of Regional Business: A Comparison of Britain and Germany', Handbook on the Geographies of Money and Finance, 125-55.

Krahnen, J. P., and Elsas, R. (2004), 'Universal Banks and Relationships with Firms', available at SSRN: https://ssrn.com/abstract=447521.

Krahnen, J. P., and Schmidt, R. H. (2004), The German Financial System, Oxford, Oxford University Press.

Kroner, N. (2011), Blueprint for Better Banking, Harriman House Publishing.

La Porta, R., Lopez-de-Silanes, F., Shleifer, A., and Vishny, R. (2000), 'Investor Protection and Corporate Governance', Journal of Financial Economics, 58(1-2), 3-27. 
Larsen, M. K., Nissen, J. L., Lueg, R., Schmaltz, C., and Thorhauge, J. R. (2014), 'Can the Business Model of Handelsbanken be an Archetype for Small and Medium Sized Banks? A Comparative Case Study', Journal of Applied Business Research (JABR), 30, 869.

Lee, N., and Brown, R. (2017), 'Innovation, SMEs and the Liability of Distance: The Demand and Supply of Bank Funding in UK Peripheral Regions', Journal of Economic Geography, 17, 233-60.

Lee, N., Sameen, H., and Cowling, M. (2015), 'Access to Finance for Innovative SMEs since the Financial Crisis', Research Policy, 44(2), 370-80.

Liberti, J. M., and Petersen, M. A. (2018), 'Information: Hard and Soft', The Review of Corporate Finance Studies, 8, 1-41.

McCann, P. (2016), The UK Regional-National Economic Problem: Geography, Globalisation and Governance, London, Routledge.

McCann, P., and Vorley, T. (eds) (2020), Productivity Perspectives, Edward Elgar.

Mason, C., and Harrison, R. (2003), 'Closing the Regional Equity Gap? A Critique of the Department of Trade and Industry's Regional Venture Capital Funds Initiative', Regional Studies, 37, 855-68.

Mason, C., and Pierrakis, Y. (2013), 'Venture Capital, the Regions and Public Policy: The United Kingdom since the Post-2000 Technology Crash', Regional Studies, 47(7), 1156-71.

Mayer, C. (2013), Firm Commitment: Why the Corporation is Failing Us and How to Restore Trust in It, Oxford, Oxford University Press.

Mayer, C. (2018), Prosperity: Better Business Makes the Greater Good, Oxford, Oxford University Press.

Mercieca, S., Schaeck, K., and Wolfeet, S. (2009), 'Bank Market Structure, Competition, and SME Financing Relationships in European Regions', Journal of Financial Services Research, 36, $137-55$.

Miles, R. E., Snow, C. C., Meyer, A. D., and Coleman, H. J. (1978), 'Organizational Strategy, Structure, and Process', The Academy of Management Review, 3, 546.

Mitchell, S. (2020a), 'Report: Fewer Small Businesses are Receiving Federal Relief Loans in States Dominated by Big Banks', 29 April, see: https://ilsr.org/banking-consolidation-pppreport/ 
Mitchell, S. (2020b), 'Banking Consolidation is Impeding Aid to Small Businesses', see: https://ilsr.org/wp-content/uploads/2020/04/ILSR_PPP_Banks_Report.pdf

NAO (2020), 'British Business Bank: Report by the Comptroller and Auditor General, Department for Business, Energy \& Industrial Strategy’, HC 21 Session 2019-20, 15 January, London.

Nguyen, H.-L. Q. (2019), ‘Are Credit Markets Still Local? Evidence from Bank Branch Closings', American Economic Journal: Applied Economics, 11(1), 1-32.

Petersen, M. A., and Rajan, R. G. (2002), 'Does Distance Still Matter? The Information Revolution in Small Business Lending', The Journal of Finance, 57, 2533-70.

Pike, A., O’Brien, P., Strickland, T., Thrower, G., and Tomaney, J. (2019), Financialising City Statecraft and Infrastructure, Cheltenham, Edward Elgar.

Puri, M., Rocholl, J., and Steffen, S. (2017), 'What Do a Million Observations Have to Say About Loan Defaults? Opening the Black Box of Relationships', Journal of Financial Intermediation, 31, 1-15.

Qi, S., De Haas, R., Ongena, S. R. G., and Straetmans, S. (2018), 'Move a Little Closer? Information Sharing and the Spatial Clustering of Bank Branches', SSRN Electronic Journal, https://doi.org/10.2139/ssrn.3250707

Reitzig, M., and Maciejovsky, B. (2014), 'Corporate Hierarchy and Vertical Information Flow inside the Firm-A Behavioral View', Strategic Management Journal, 36, 1979-99.

Reuters (2016), 'Britain's Poorer Communities, Hit Hardest by Bank Closures, May Face Shut Out', see: http://uk.reuters.com/article/uk-britain-banks-branches-idUKKCN0Z60BP

Sensier, M. (2017), 'Financing Inclusive Growth with a Greater Manchester Community Bank', University of Manchester, Briefing Paper No. 3, May.

Sette, E., and Gobbi, G. (2015), 'Relationship Lending During a Financial Crisis', Journal of the European Economic Association, 13(3), 453-81.

Simpson, C. (2013), The German Sparkassen (Savings Banks), London, Civitas.

Singh, A., Hall, M., and Toner, E. (2020), 'The Road to Resilience: How Community Financial Services can Help Level Up Britain', Report, Royal Society of Arts, June.

Stein, J. C. (2002), 'Information Production and Capital Allocation: Decentralized versus Hierarchical Firms', The Journal of Finance, 57, 1891-921. 
Tenca, F., Croce, A., and Ughetto, E. (2018), 'Business Angels Research in Entrepreneurial Finance: A Literature Review and Research Agenda', Journal of Economic Surveys, 32(5), $1384-413$.

The Economist (2019), 'They Know Their Customers-The State of America's Community Banks: Don't Write off the Admirable Bantamweights of the Industry', 9 May, see: https://www.economist.com/finance-and-economics/2019/05/11/the-state-of-americascommunity-banks

Ughetto, E., Cowling, M., and Lee, N. (2019), 'Regional and Spatial Issues in the Financing of Small and Medium-sized Enterprises and New Ventures', Regional Studies, 53(5), 61719.

Verdier, D. (2009), Moving Money: Banking and Finance in the Industrialized World, Cambridge, Cambridge University Press.

Whittington, R. (2006), Organizational Structure, Oxford, Oxford University Press.

Wójcik, D., and MacDonald-Korth, D. (2015), 'The British and the German Financial Sectors in the Wake of the Crisis: Size, Structure and Spatial Concentration', Journal of Economic Geography, 15, 1033-54.

Zhao, T., and Jones-Evans, D. (2017), 'SMEs, Banks and the Spatial Differentiation of Access to Finance', Journal of Economic Geography, 17, 791-824. 